\title{
Signaling pathway involved in cyclooxygenase-2 up-regulation by hepatocyte growth factor in endometrial cancer cells
}

\author{
YORIKO YOSHIZAWA, YOSHIHIKO YAMADA, SEIJI KANAYAMA, HIROSHI SHIGETOMI, RYUJI KAWAGUCHI, \\ SHOZO YOSHIDA, AKIRA NAGAI, NAOTO FURUKAWA, HIDEKAZU OI and HIROSHI KOBAYASHI
}

Department of Obstetrics and Gynecology, Nara Medical University, Kashihara, Nara 634-8522, Japan

Received April 14,2011; Accepted May 23, 2011

DOI: $10.3892 /$ or.2011.1348

\begin{abstract}
Hepatocyte growth factor (HGF) is up-regulated in tissue repair and has been implicated in playing a role in this process through its anti-apoptotic and proliferative activities. Cyclooxygenase-2 (COX-2) is an inducible enzyme in the biosynthetic pathway of prostaglandins, and its activation has been shown to play an important role in cell growth. We previously reported that HGF significantly inhibited anoikis, possibly through the up-regulation of COX-2 expression in the endometrial RL95-2 cancer cell line. Here, we report that i) treatment of RL95-2 cells with HGF resulted in phosphorylation of the HGF receptor c-Met, activation of Akt and IкB, translocation of NF- $\mathrm{KB}$ into the nucleus, and up-regulation of COX-2 mRNA; ii) the I $\mathrm{BB}-\alpha$ phosphorylation inhibitor BAY117082 and the selective COX-2 inhibitor CAY10452 blocked HGF-mediated anoikis resistance in RL95-2 cells; and iii) HGF induced migration and invasion in RL95-2 cells, while the phosphatidylinositol 3-kinase (PI3K) inhibitor LY294002 and CAY10452 blocked these effects of HGF stimulation. Our data suggest that HGF possesses chemotactic ability, has antiapoptosis action, and induces cellular infiltration via the PI3K/ Akt pathway; it also triggers NF- $\kappa \mathrm{B}$ activation and up-regulates $\mathrm{COX}-2$ gene expression in endometrial cancer cells.
\end{abstract}

\section{Introduction}

Hepatocyte growth factor (HGF), also known as the scatter factor, was identified and cloned as a mitogen of hepatocytes $(1,2)$. During organ development and tissue repair, HGF acts as a pleiotropic cytokine with regenerative, protective, and angiogenic properties, and it displays these functions by binding to its receptor, c-Met (3). HGF and c-Met are often overexpressed in human cancers, including gastrointestinal

Correspondence to: Dr Yoshihiko Yamada, Department of Obstetrics and Gynecology, Nara Medical University, 840 Shijo-cho, Kashihara, Nara 634-8522, Japan

E-mail: yoshi-ch@naramed-u.ac.jp

Key words: cyclooxygenase-2, hepatocyte growth factor, anoikis, invasion, migration, endometrial cancer
(4), renal (5), head and neck (6), lung (7), pancreatic (8) and endometrial cancers (9). Recent studies suggest that the interaction between HGF and c-Met stimulates tumor growth (10) and angiogenesis $(11,12)$ and suppresses tumor apoptosis in various malignant tumors (13). In endometrial cancer, it has been observed that HGF is secreted by endometrial stromal cells and that endometrial cancer cells express its receptor c-Met (14). The interaction between HGF and c-Met is involved in the effects of HGF on tumor invasion (14-16), angiogenesis (9) and anti-apoptosis (17).

Cyclooxygenase-2 (COX-2) is the rate-limiting step in the production of prostaglandins and is expressed at high levels only upon induction by growth factors, cytokines, and extracellular stimuli associated with cell activation (18). COX-2 is reportedly involved in chronic inflammation and cancer growth $(19,20)$. COX-2 mediates a number of effects, including stimulation of invasion and motility, angiogenesis, and protection from apoptosis (21). All of these effects are also linked to HGF, suggesting that COX-2 may be an important downstream mediator of HGF effects (22). In endometrial cancer, the overexpression of COX-2 is closely associated with parameters of tumor aggressiveness (23). Moreover, recent reports indicate that COX-2 inhibitors may be effective in the treatment of endometrial cancer via the suppression of angiogenesis (24).

Anoikis is a form of apoptosis induced in epithelial cells through loss of their matrix attachment and is involved in a wide diversity of tissue-homeostatic, developmental, and oncogenic processes. In contrast to the fate of normal cells, tumor cells metastasize upon the loss of their matrix attachment. Hence, the inhibition of anoikis is a key element in tumor progression and metastasis (25-27).

We previously reported that HGF significantly inhibited anoikis, possibly through the up-regulation of COX-2 expression in endometrial cancer (28). Our previous report was the first to report the relationship between anoikis and gynecological cancer. However, the signaling pathway involved in the up-regulation of COX-2 expression by HGF stimulation in endometrial cancer cells remains unknown. In this study, we demonstrated that HGF up-regulates COX-2 through the $\mathrm{NF}-\mathrm{KB}$ and the PI3K/Akt pathways in endometrial cancer cells and that HGF stimulation enhances chemotaxis ability, cellular infiltration and anoikis resistance in uterine cancer cells. 


\section{Materials and methods}

Reagents. Recombinant human hepatocyte growth factor (HGF) was purchased from Peprotech Inc. (Rocky Hill, NJ, USA). PD98059, an inhibitor of mitogen-activated protein kinase kinase activation, was obtained from Biomol Research Labs, Inc. (Plymouth Meeting, PA, USA). LY294002, a PI3K/ Akt inhibitor, was purchased from Calbiochem. BAY11-7082, an inhibitor of IкB- $\alpha$ phosphorylation, was from SigmaAldrich (St. Louis, MO, USA). CAY10452, a selective COX-2 inhibitor, was purchased from Cayman Chemical Company (Ann Arbor, MI, USA). Fetal bovine serum (FBS) was obtained from Invitrogen, Carlsbad, CA, USA. Furthermore, $100 \mathrm{U}$ penicillin and $100 \mathrm{U}$ streptomycin were purchased from ICN Biomedicals Inc. (Aurora, OH, USA).

Cell culture. The human endometrial cancer cell line RL95-2 was obtained from the American Type Culture Collection (Manassas, VA, USA). RL95-2 cells were grown in Dulbecco's modified Eagle's medium/nutrient mixture F-12 (DMEM/F12) supplemented with $10 \%$ FBS, penicillin $(100 \mathrm{U} / \mathrm{ml})$, and streptomycin $(100 \mathrm{Ag} / \mathrm{ml})$. DMEM/F-12 was purchased from Sigma-Aldrich. Cells were cultured in $75-\mathrm{cm}^{2}$ bottles at $37^{\circ} \mathrm{C}$ in $95 \%$ air and $5 \% \mathrm{CO}_{2}$. At the log growth phase, the cells were seeded into 6-well plates and then serum-starved for $12 \mathrm{~h}$ prior to the experiments.

Induction of anoikis. To prevent cell adhesion, culture dishes were coated with diluted poly-HEMA solution and ethanol solvent, and then evaporated overnight as described by Folkman and Moscona (29). Cultured cells were plated at a concentration of $7 \times 10^{5} / \mathrm{ml}$ on culture dishes. Next, the cells were cultured in DMEM/F-12 supplemented with $1 \%$ FBS for $48 \mathrm{~h}$ in suspension.

Protein extraction. Total protein was extracted from whole RL95-2 cells plated in 6-well dishes using M-PER mammalian protein extraction reagent (Pierce, USA) with $1 \%$ Halt $^{\mathrm{TM}}$ protease inhibitor cocktail (Pierce) according to the manufacturer's instructions. We added phosphatase inhibitor Cocktails B and C (Santa Cruz Biotechnology Inc., Santa Cruz, CA, USA) upon detection of phosphorylation. The protein concentration was measured using a DC protein assay (Bio-Rad) according to the manufacturer's protocol.

Nuclear extractions. Nuclear extractions were prepared from whole RL95-2 cells plated in 6-well dishes using NE-PER nuclear and cytoplasmic extraction reagents (Pierce) with $1 \%$ Halt protease inhibitor cocktail (Pierce), according to the protocol suggested by the manufacturer.

Western blot analysis. The lysates were separated using $10 \%$ sodium dodecyl sulfate-polyacrylamide gel electrophoresis under reducing conditions. After electrophoresis, the proteins on the gel were transferred onto a polyvinylidene difluoride membrane. The membrane was then washed with Trisbuffered saline (TBS; Santa Cruz Biotechnology) containing $0.1 \%$ Tween-20 (TBST) and blocked with Blocking One-P (Nakarai Tesque Inc., Kyoto, Japan) at $4^{\circ} \mathrm{C}$ overnight. Next, the membrane was probed with primary antibodies for $12 \mathrm{~h}$ at $4^{\circ} \mathrm{C}$. The following primary antibodies were purchased from the following commercial sources. The anti-human IкB- $\alpha$, p-IкB- $\alpha$, c-Met, p-Met and COX-2 rabbit polyclonal antibodies (dilution, 1:1000) were purchased from Santa Cruz Biotechnology, and the anti-human NF- $\kappa \mathrm{B}$ p65 rabbit polyclonal antibody (ab31481; dilution, 1:10000) and anti-human Lamin A/C mouse monoclonal antibody (ab8984; dilution 1:2000) were from Abcam Cambridge, UK. The anti-human Akt and phospho-Akt rabbit monoclonal antibodies (dilution, 1:10,000) were from Cell Signaling Technology, Inc., USA, and the anti-human $\beta$-actin rabbit monoclonal antibody (dilution, 1:10000) was from Epitomics Inc. (Burlingame, CA, USA). After the membrane was washed with TBST, the antibodies bound to the membrane were detected with anti-rabbit immunoglobulin $\mathrm{G}$ conjugated to horseradish peroxidase (HRP) (GE Healthcare UK Ltd., Buckinghamshire, UK) and anti-mouse immunoglobulins/HRP (dilution, 1:10,000; DakoCytomation, Glostrup, Denmark) and visualized with the ECL Plus Western blotting detection system (GE Healthcare UK Ltd.) according to the manufacturer's protocol. After the membrane was washed with TBST, the membrane was reprobed with Restore $^{\mathrm{TM}}$ Plus Western Blot stripping buffer (Pierce).

Densitometry of Western blot data. Images of blots were entered into a computer using a scanner (LAS-1000; FujiFilm Corp., Tokyo, Japan) and analyzed using the software program Image Gauge (FujiFilm Corp.).

Real-time polymerase chain reaction (real-time PCR). Total RNA was reverse transcribed in a 50- $\mu$ l volume with the TaqMan Gene Expression Cells-to-Ct ${ }^{\mathrm{TM}}$ kit (Applied Biosystems, Foster City, CA, USA) according to the manufacturer's recommendations. After RL95-2 cells grown in 96-well plates were washed in PBS, they were incubated for $5 \mathrm{~min}$ at room temperate in the supplied lysis solution with DNase in order to lyse the cells and remove the gDNA. Next, the samples were incubated in stop solution for $2 \mathrm{~min}$ at room temperature. Samples were then processed directly in the culture well. Reverse transcription was carried out by using the Thermal Cycler Personal (Takara Bio Inc., Japan). Samples were incubated at $37^{\circ} \mathrm{C}$ for $60 \mathrm{~min}$ and then at $95^{\circ} \mathrm{C}$ for $5 \mathrm{~min}$ to inactivate the reverse transcriptase enzyme. Next, $4 \mu \mathrm{l}$ of the reverse transcription reaction mixture was used in each of the real-time PCR assays. Quantitative real-time PCR was performed with the TaqMan Gene Expression Cells-to-Ct kit according to the manufacturer's recommendations. The primers for COX-2 and the housekeeping gene GAPDH were used for the TaqMan Gene Expression Assay (Applied Biosystems). The assay ID of the primer for COX-2 was Hs01573471_m1 and that for GAPDH was Hs99999905_g1. Samples were denatured at $50^{\circ} \mathrm{C}$ for $2 \mathrm{~min}$ and at $95^{\circ} \mathrm{C}$ for $10 \mathrm{~min}$, followed by 55 cycles each of $95^{\circ} \mathrm{C}$ for $15 \mathrm{sec}$ and $60^{\circ} \mathrm{C}$ for $1 \mathrm{~min}$, and then held at $25^{\circ} \mathrm{C}$ on the StepOne ${ }^{\mathrm{TM}}$ real-time PCR system (Applied Biosystems).

Data normalization. Relative quantification of gene expression was calculated using the $2^{-\Delta \Delta \mathrm{Ct}}$ method. The delta-delta method was used to determine the relative levels of mRNA expression between experimental samples and controls. The relative quantification is based on a reference mRNA, which 
has a consistent level of mRNA expression under existing experimental sample and control sample conditions. In the present study, GAPDH was selected as the reference gene for the normalization of inter-PCR variation. Because of the exponential amplification of target genes by the real-time $\mathrm{PCR}$ reaction, a $\Delta \Delta \mathrm{CT}=1$ was considered to represent a 2 -fold change in target gene expression.

Methionyl-tRNA synthetase (MTS) proliferation assay. Cell viability was measured using the MTS proliferation assay using the Cell Titer 96 Aqueous One solution cell proliferation assay (Promega Corp., Madison, WI, USA) according to the manufacturer's instructions. Briefly, MTS solution (20 $\mu \mathrm{l} /$ well) was added, and after $2 \mathrm{~h}$ of culture at $37^{\circ} \mathrm{C}$ in $95 \%$ air and $5 \% \mathrm{CO}_{2}$, the conversion of MTS to formazan was measured on a plate reader at $492 \mathrm{~nm}$. The percentage of cell viability/cell death was determined by a comparison with untreated controls.

Cell culture wound healing assay. RL95-2 cells were seeded onto 24-well dishes and grown to overconfluence for $24 \mathrm{~h}$. Upon reaching overconfluence, the center of the culture dishes was scraped once with a $200-\mu 1$ yellow pipette tip. After washing away the debris, the cells were re-fed fresh medium with or without pharmacological inhibitor and HGF. Images of each well were examined under an Olympus microscope (Tokyo, Japan), and the width of each wound was photographed and measured after 0 and $24 \mathrm{~h}$ using an Olympus sc35 camera. The area of the denuded surface was quantified immediately after wounding and again after $24 \mathrm{~h}$. The extent of wound closure was determined by calculating the ratio between the surface area of the wound for each time point and the surface of the initial wound. These data were then expressed as the percentage of wound closure relative to the control conditions for each experiment.

Invasion assay. The invasion assay was performed by using 24-well BD BioCoat Matrigel invasion chambers with $8-\mu \mathrm{m}$ polycarbonate filters (Becton-Dickinson, Bedford, MA, USA). Fifty thousand RL95-2 cells were seeded onto the upper chamber of the Matrigel invasion chamber plates and cultured in $500 \mu \mathrm{l}$ serum-free medium in the absence or presence of a pharmacological inhibitor. In the lower chamber, DMEM/ F-12 with $5 \%$ FBS in the absence or presence of $10 \mathrm{ng} / \mathrm{ml}$ of HGF was loaded. Cells were incubated for $34 \mathrm{~h}$ at $37^{\circ} \mathrm{C}$ in a humidified incubator with $5 \% \mathrm{CO}_{2}$. Migrating cells on the upper surface of the filter were removed by wiping with a cotton swab. Invasive cells that penetrated through the pores and that migrated to the underside of the membrane were stained with Diff-Quik (Sysmex Corp., Kobe, Japan). The transwell membranes were cut, mounted on glass slides upside down, immersed in a diluted glycerol solution (1:10 in PBS), and observed under a microscope. After selecting 5 regions of each membrane randomly, the number of cancer cells that had migrated to be trapped in the pores was counted. Images of the chamber membranes were viewed under the Olympus microscope, BX41, and photographed using the Olympus DP20 camera and Olympus DP2-BSW software.

Statistical analysis. Each experiment was performed in triplicate. Values are expressed as the mean [standard deviation
(SD)]. Differences between groups were analyzed using the Student's t-test and analysis of variance (ANOVA). A value of $\mathrm{p}<0.05$ was considered statistically significant.

\section{Results}

HGF phosphorylation of c-met, Akt and I $\kappa B$ in RL95-2 cells. We re-examined whether the PI3/Akt and NF- $\kappa \mathrm{B} / \mathrm{I} \kappa \mathrm{B}$ signaling pathways are activated by HGF stimulation by using Western blot analysis. RL95-2 cells in 6-well dishes were incubated with varying concentrations of $\mathrm{HGF}$ for $5 \mathrm{~min}$. Next, $10 \mu \mathrm{g}$ of the protein extracts was analyzed by Western blot analysis. A very low amount of phosphorylated c-Met (p-Met) was detected in the control cells, while the concentration of p-Met was increased in the extracts of cells stimulated with 5 and $10 \mathrm{ng} / \mathrm{ml}$ of HGF. Similarly, very low amounts of phosphorylated Akt (p-Akt) and phosphorylated IкB (p-IкB) were detected in the control cells. Meanwhile, the concentrations of p-Akt and $\mathrm{p}-\mathrm{I} \kappa \mathrm{B}$ were increased in the extracts of cells stimulated with $10 \mathrm{ng} / \mathrm{ml}$ of HGF. However, pretreatment with LY294002 before the addition of HGF did not increase the concentrations of $\mathrm{p}-\mathrm{I} \kappa \mathrm{B}$ and $\mathrm{p}-\mathrm{Akt}$, and PD98059 failed to inhibit the effect of HGF (Fig. 1).

RL95-2 cells in 6-well dishes were incubated with or without HGF for $5 \mathrm{~min}$. Next, $5 \mu \mathrm{g}$ of nuclear extracts were analyzed by Western blot analysis. The concentrations of $\mathrm{NF}-\kappa \mathrm{B}$ in the nucleus were significantly increased in the extracts of cells stimulated with $20 \mathrm{ng} / \mathrm{ml}$ of HGF $(\mathrm{p}<0.05)$. Pretreatment with LY294002 $(10 \mu \mathrm{M})$ and BAY11-7082 $(10 \mu \mathrm{M})$, an I $\mathrm{B} \mathrm{B}-\alpha$ phosphorylation inhibitor, prior to the addition of HGF significantly decreased the concentration of $\mathrm{NF}-\kappa \mathrm{B}$ in the nucleus $(\mathrm{p}<0.05)$. However, PD98059 $(20 \mu \mathrm{M})$ failed to block the effect of HGF (Fig. 2). These results suggest that $\mathrm{HGF}$ activates the PI3K/Akt and $\mathrm{NF}-\kappa \mathrm{B} / \mathrm{I} \kappa \mathrm{B}$ signaling pathways in RL95-2 cells.

Effect of HGF on the expression of COX-2 mRNA in RL95-2 cells. We previously reported that HGF stimulates COX-2 protein expression in RL95-2 cells (28), but we have yet to examine COX-2 mRNA expression. The transcription factor $\mathrm{NF}-\kappa \mathrm{B}$ was found to function upstream of COX-2 in colon cancer (30-32). Therefore, we tested whether HGF has an effect on the expression of COX-2 mRNA in RL95-2 cells. For this purpose, RL95-2 cells in 96-well plates were incubated with varying concentrations of HGF for $12 \mathrm{~h}$, with some of the plates pretreated with BAY11-7082 $(1 \mu \mathrm{M})$ for $1 \mathrm{~h}$ prior to HGF stimulation. As shown by real-time PCR, the COX-2 gene expression levels significantly increased in the extracts of cells stimulated with 1,5 and $10 \mathrm{ng} / \mathrm{ml}$ of HGF $(\mathrm{p}<0.05)$. Pretreatment with BAY11-7082 prior to the addition of HGF significantly decreased the gene expression levels of COX-2, relative to treatment with $\mathrm{HGF}$ alone $(\mathrm{p}<0.05)$ (Fig. 3A). These results suggest that HGF stimulates COX-2 mRNA expression through the activation of NF- $\kappa \mathrm{B}$ in RL95-2 cells.

HGF stimulation of COX-2 expression in RL95-2 cells through the PI3/Akt and $N F-\kappa B / I \kappa B$ pathways. Next, we used pharmacological inhibitors to elucidate the signaling pathway for COX-2 induction. RL95-2 cells in 6-well dishes were incubated with or without $5 \mathrm{ng} / \mathrm{ml}$ of HGF for $24 \mathrm{~h}$, with some 
A

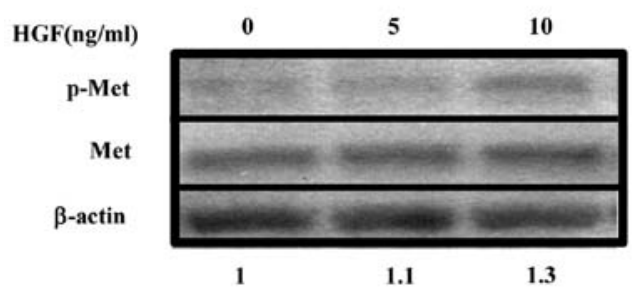

B
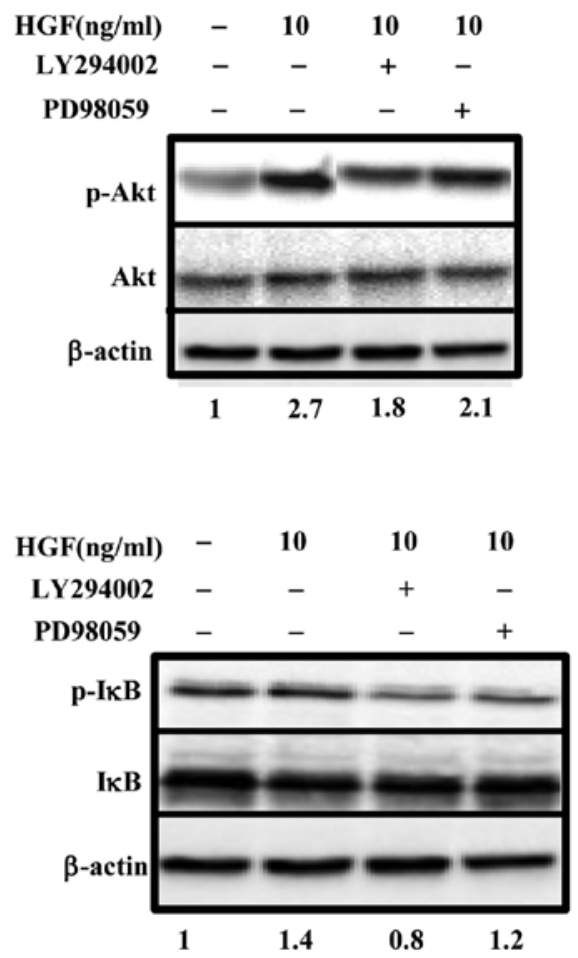

Figure 1. Effect of HGF on the phosphorylation of c-Met, Akt, and IкB in RL95-2 cells. RL95-2 cells cultured in suspension in 6-well dishes were incubated with varying concentrations of HGF for $5 \mathrm{~min}$. Protein extracts $(10 \mu \mathrm{g})$ were subjected to an immunoblot assay to detect the phosphorylation of (A) c-Met and (B) Akt and IкB. $\beta$-actin served as an equal loading control. The numbers below each gel band represent the densitometric band density ratios of the phosphorylated forms of c-Met, Akt and IкB. P-Met, phosphorylated c-Met; p-Akt, phosphorylated Akt; and p-IкB, phosphorylated IкB.

dishes pretreated with the pharmacological inhibitors before the addition of HGF. Protein extracts were then analyzed by Western blot analysis. Relative to the control, which showed a very low amount of COX-2 protein, the levels of COX-2 protein were higher in the extracts of cells stimulated with $5 \mathrm{ng} / \mathrm{ml}$ of HGF. Pretreatment with LY294002 $(10 \mu \mathrm{M})$ and BAY11-7082 $(1 \mu \mathrm{M})$ before the addition of HGF did not increase COX-2 protein concentrations. PD98059 $(20 \mu \mathrm{M})$ failed to inhibit the effect of HGF (Fig. 3B). These results suggest that HGF stimulates COX-2 expression in RL95-2 cells through the PI3/Akt and NF- $\kappa \mathrm{B} / \mathrm{I} \kappa \mathrm{B}$ pathways.

$H G F$ inhibition of anoikis by activation of $N F-\kappa B$ and up-regulation of COX-2. We previously reported that HGF inhibited anoikis through the PI3K/Akt pathway in RL95-2
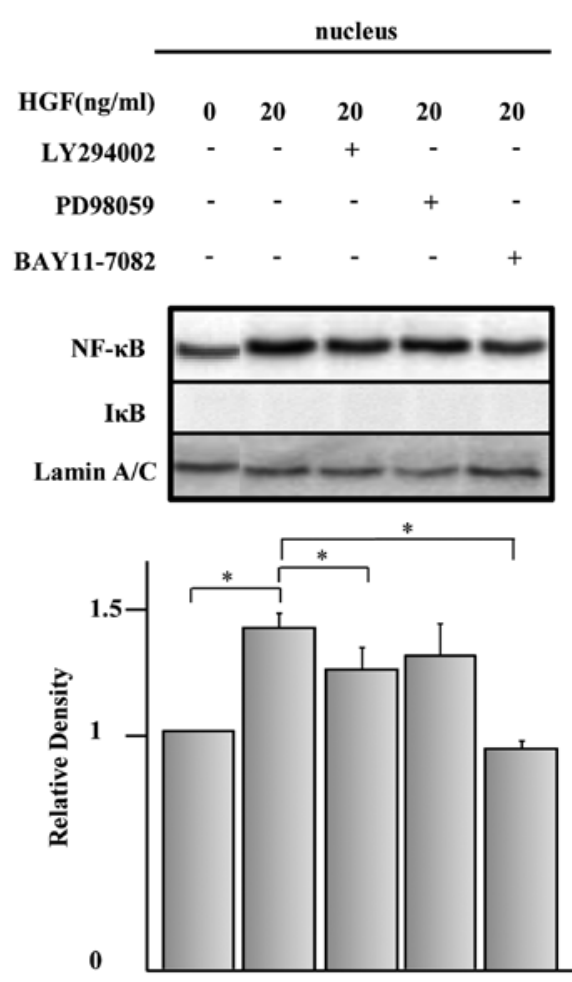

Figure 2. Effect of HGF on the nuclear translocation of NF-кB in RL95-2 cells. RL95-2 cells cultured in suspension in 6-well dishes were incubated with or without HGF for $5 \mathrm{~min}$. Some dishes were pretreated by the pharmacological inhibitors LY294002 $(10 \mu \mathrm{M})$, PD98059 $(20 \mu \mathrm{M})$ or BAY11-7082 $(10 \mu \mathrm{M})$ prior to the addition of HGF. Nuclear extracts $(5 \mu \mathrm{g})$ were subjected

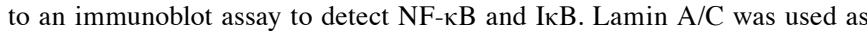
an internal markers for nuclear proteins. Upper panel shows the Western blot

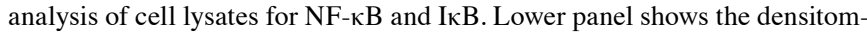
etry analysis of NF- $\kappa \mathrm{B}$ and I $\mathrm{B}$ when compared with the density of untreated cell lysates. The mean and SD of 3 treatments are presented. ${ }^{*} \mathrm{p}<0.05$.

cells (28). Here, we examined downstream of the PI3K/ Akt signaling pathway and investigated whether activation of NF- $\mathrm{KB}$ is involved in the HGF effect on anoikis. RL95-2 cells were plated on tissue culture dishes coated with polyHEMA in the absence or presence of HGF (10 and $20 \mathrm{ng} /$ $\mathrm{ml})$. Some dishes were pretreated with either BAY11-7082 $(8 \mu \mathrm{M})$ or CAY10452 $(10 \mu \mathrm{M})$, a selective COX-2 inhibitor, for $1 \mathrm{~h}$ before HGF stimulation. After $48 \mathrm{~h}$ of incubation, the viability of floating cells was measured by the MTS proliferation assay. Incubation with HGF significantly increased cell survival [10 ng/ml HGF: $80.8 \%$ (SD, 5.6\%); $20 \mathrm{ng} / \mathrm{ml}$ HGF: $75.8 \%(6.8 \%)]$ compared with the control samples [68.1\% (8.5\%)] (Fig. 4). Pretreatment with BAY11-7082 significantly blocked HGF-mediated anoikis resistance [10 ng/ml HGF: 71.6\% (6.9\%); $20 \mathrm{ng} / \mathrm{ml}$ HGF: 68.6\%, (8.3\%)]. Pretreatment with CAY10452 also succeeded in inhibiting HGF-mediated anoikis resistance [10 ng/ml HGF: 69.0\% (5.8\%); $20 \mathrm{ng} / \mathrm{ml}$ HGF: $68.3 \%(6.3 \%)]$.

Effects of HGF on cell migration. We examined the effect of HGF on the migratory capacity of RL95-2 cells. This cell line has been shown to migrate but not proliferate after treatment with HGF in vitro (14). We confirmed that RL95-2 cells did not proliferate after the addition of HGF (data not shown). Involvement of the c-Met-PI3K-Akt cascade in the migration 
A

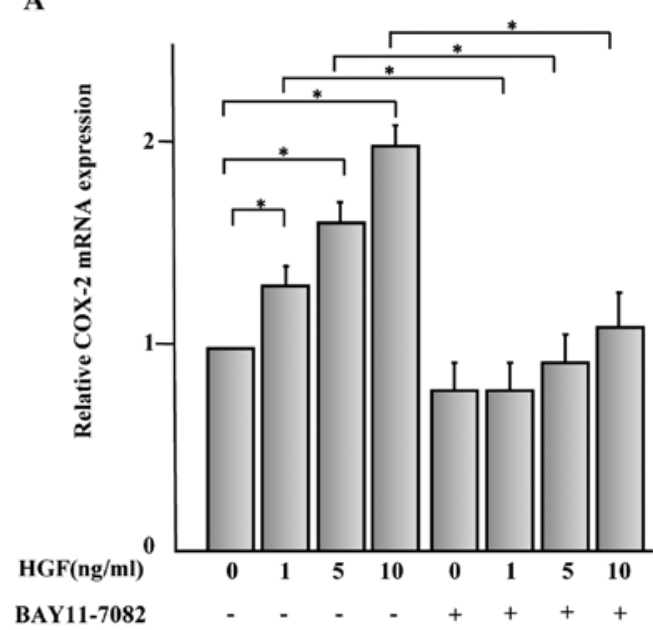

B

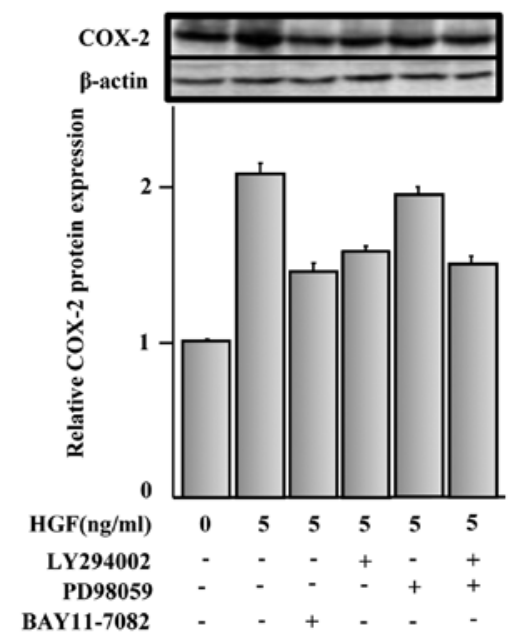

Figure 3. HGF stimulates COX-2 protein expression through the PI3/Akt and NF- $\mathrm{KB} / \mathrm{I} \kappa \mathrm{B}$ pathways. (A) RL95-2 cells in 96-well plates were incubated with varying concentrations of HGF for $12 \mathrm{~h}$. Some of the plates were pretreated with BAY11-7082 $(1 \mu \mathrm{M})$ for $1 \mathrm{~h}$ before HGF stimulation Gene expression levels of COX-2 were analyzed by real-time PCR. Each value represents mean and SD from 3 independent experiments. ${ }^{*} \mathrm{p}<0.05$ (B) RL95-2 cells in 6-well dishes were incubated with or without $5 \mathrm{ng} / \mathrm{ml}$ of HGF for $24 \mathrm{~h}$. Some dishes were pretreated with the pharmacological inhibitors LY294002 $(10 \mu \mathrm{M})$, PD98059 $(20 \mu \mathrm{M})$, or BAY11-7082 $(10 \mu \mathrm{M})$ prior to the addition of HGF. Protein extracts were analyzed by Western blot analysis. Protein levels were determined by densitometry. $\beta$-actin served as an equal loading control. Each value represents the mean and SD from 3 independent experiments. " $\mathrm{p}<0.05$.

of endometrial cancer cells was confirmed by the wound healing assay. Moreover, abrogation of the wound healing process was observed after pretreatment with LY294002 (5 $\mu \mathrm{M})$ and CAY10452 $(10 \mu \mathrm{M})$ (Fig. 5), further providing evidence that the HGF-induced migration of endometrial cancer cells may be regulated by COX-2 through the PI3K/ Akt signal cascade.

Effect of HGF on cell invasion. We examined the effect of HGF on the invasive ability of RL95-2 cells. As seen in Fig. 6, HGF significantly increased the invasiveness of RL95-2 cells relative to the control $(\mathrm{p}<0.05)$. Pretreatment with LY294002 $(5 \mu \mathrm{M})$ or CAY10452 $(10 \mu \mathrm{M})$ significantly blocked the effect of HGF.
A

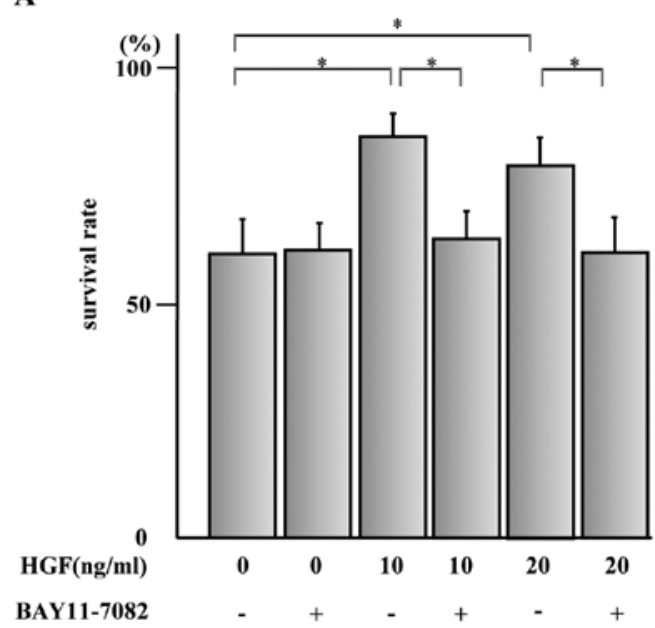

B

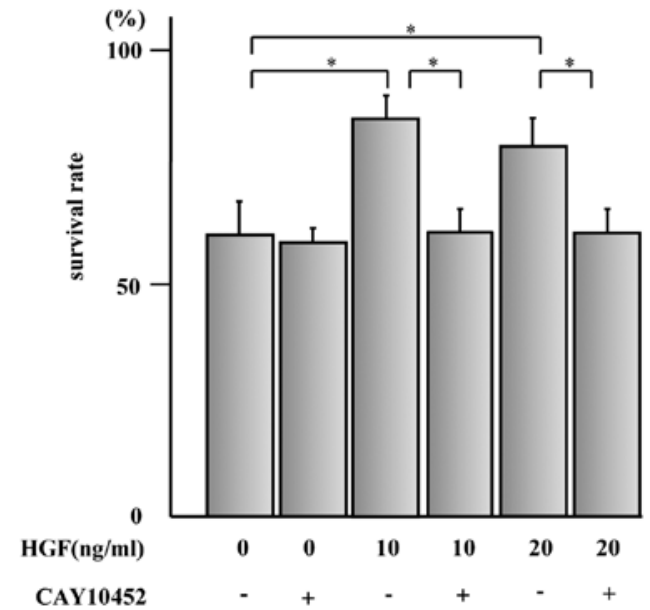

Figure 4. Effects of BAY11-7082 and CAY10452 on HGF-mediated anoikis resistance in RL95-2 cells. RL95-2 cells cultured in suspension in 6-well dishes were incubated with or without HGF. Some dishes were pretreated with BAY11-7082 $(8 \mu \mathrm{M})$ and CAY10452 $(10 \mu \mathrm{M})$, a selective COX-2 inhibitor, for $1 \mathrm{~h}$ before HGF stimulation. After a 48 -h incubation, the viability of the floating cells was measured by the MTS proliferation assay. The survival rate was determined by setting the absorbance of the non-treated control cells to $100 \%$. Each value represents the mean and SD of triplicates from 3 independent experiments. ${ }^{*} \mathrm{p}<0.05$.

\section{Discussion}

We showed here that HGF up-regulates COX-2 through the $\mathrm{NF}-\kappa \mathrm{B}$ and PI3K/Akt pathways in endometrial cancer cells and that HGF increases invasion, migration and resistance to anoikis by up-regulating COX-2 expression.

We previously reported that HGF significantly inhibited anoikis in endometrial cancer cells by up-regulating COX-2 expression (28). However, the intracellular signal transduction of COX-2 up-regulation by HGF stimulation has not yet been elucidated. Previous studies have reported that activation by HGF occurs primarily through two kinase cascades: the extracellular signal-related kinase (ERK) and PI3K/Akt signaling pathways (18-20). It has been reported that HGF inhibits anoikis in head and neck squamous cell carcinoma cells by activation of both the ERK and Akt signaling pathways (19). Sequencing of the human COX-2 promoter region 
A

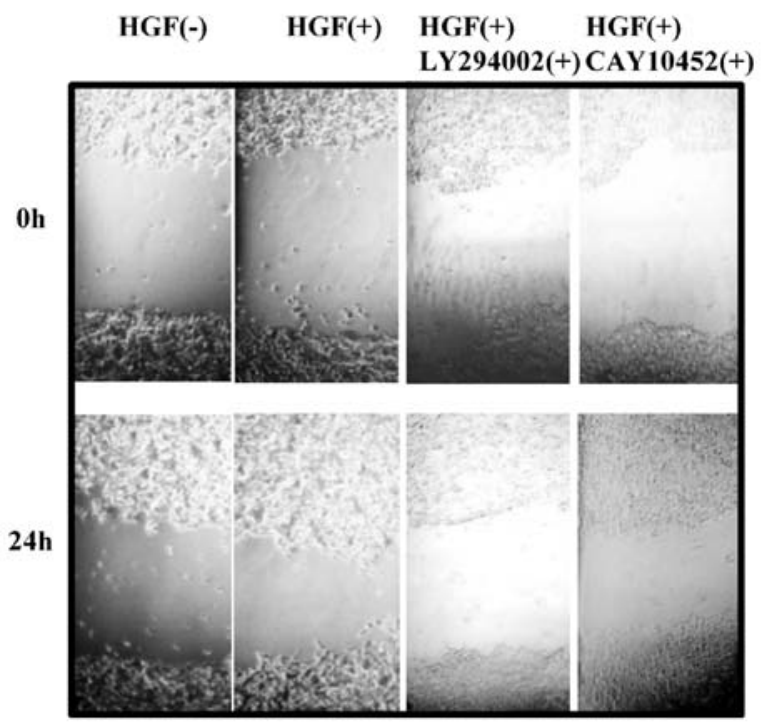

B

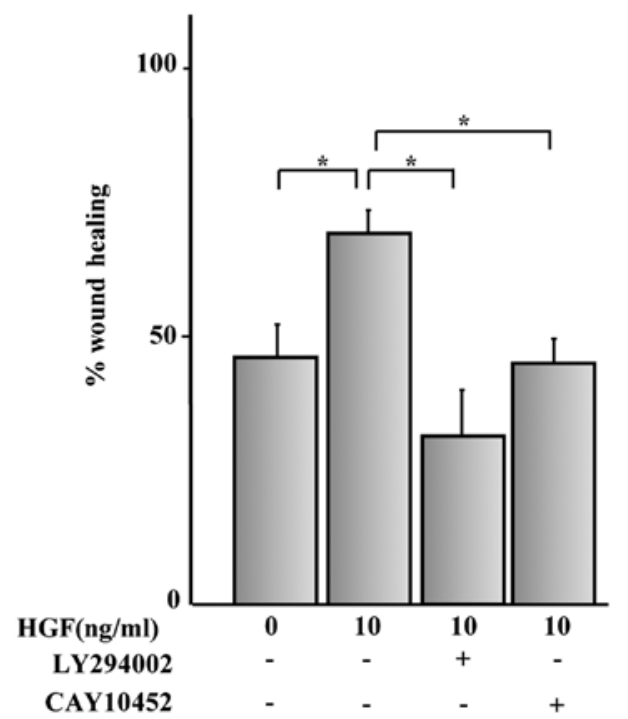

Figure 5. Effects of HGF on cell migration in RL95-2 cells. RL95-2 cells were grown to overconfluence. The center of the culture dishes was scraped once with a pipette tip. The migration of cells into the wound area was documented and evaluated after $24 \mathrm{~h}$. Quantitative analysis of the percentage of wound healing was calculated using distances across the wound at 0 and $24 \mathrm{~h}$. (A) Images of the cultures were captured immediately after the incision and after $24 \mathrm{~h}$ in culture. $\mathrm{HGF}(+)$ : $\mathrm{HGF}$ at $10 \mathrm{ng} / \mathrm{ml}$; HGF(+) LY294002(+): $\mathrm{HGF}$ at $10 \mathrm{ng} / \mathrm{ml}$ with $10 \mu \mathrm{M}$ LY294002; HGF(+) CAY10452(+): HGF at $10 \mathrm{ng} / \mathrm{ml}$ with $10 \mu \mathrm{M}$ CAY10452. (B) The extent of wound closure was determined after $24 \mathrm{~h}$ of incubation. Each value represents the mean and SD of triplicates from 3 independent experiments. ${ }^{*} \mathrm{p}<0.05$.

has revealed the presence of $\mathrm{NF}-\kappa \mathrm{B}$ consensus sites, which are important in the induction of COX-2 gene expression (33). $\mathrm{NF}-\kappa \mathrm{B}$ is an essential transcription factor in the expression of vital genes as well as a number of genes involved in immune, inflammatory and growth responses $(34,35)$. NF- $\kappa \mathrm{B}$ is present in the cytosol in an inactive form as a heterodimer of p50 and p65 subunits bound to one of the I $\mathrm{B}$ inhibitory proteins. Akt rapidly phosphorylates I $\kappa$ B- $\alpha$ by an I $\mathrm{B}$ kinase (IKK), resulting in its ubiquitination and proteolytic degradation
A

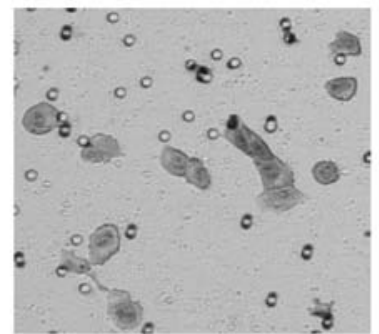

HGF(-)

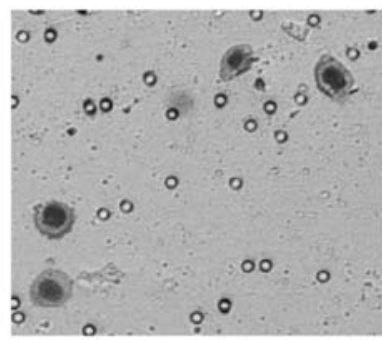

HGF(+) LY294002(+)

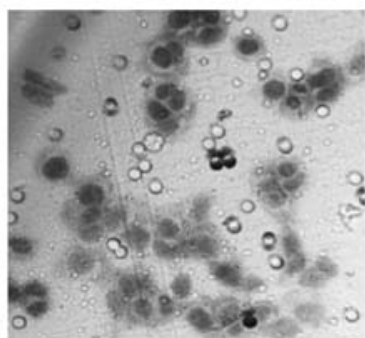

HGF(+)

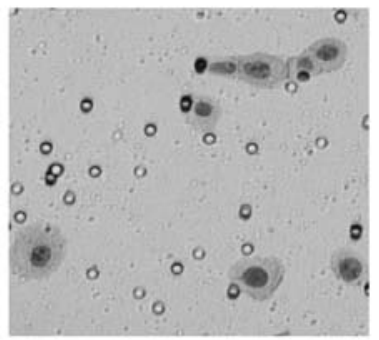

HGF(+) CAY10452(+)
B

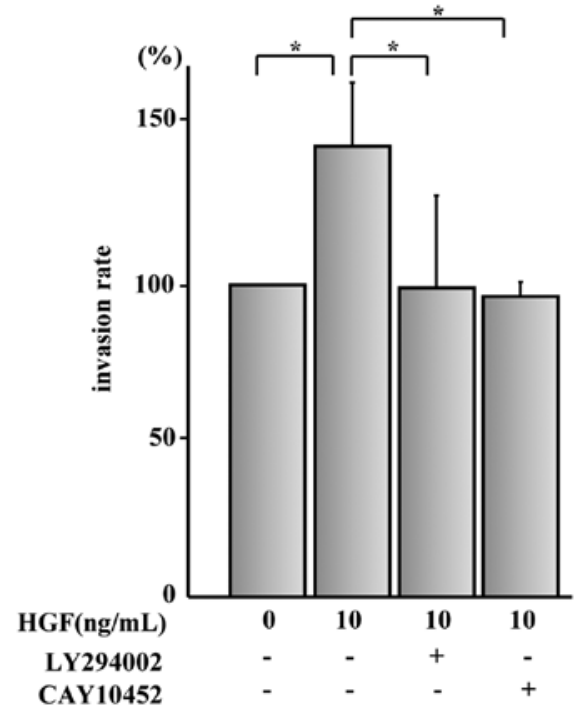

Figure 6. Effect of HGF on cell invasion in RL95-2 cells. The invasion assay was performed. RL95-2 cells were seeded on upper chamber plates and cultured in a serum-free medium in the absence or presence of a pharmacological inhibitor. In the lower chamber, DMEM/F-12 with 5\% FBS in the absence or presence of HGF was loaded. Cells were incubated for $34 \mathrm{~h}$. Invasive cells that penetrated through the pores and migrated to the underside of the membrane were stained with Diff-Quik. After selecting 5 regions randomly, the number of cancer cells that had migrated was counted. (A) The cell images are representatives of membranes of the chamber insert. $\mathrm{HGF}(+)$ : $\mathrm{HGF}$ at $10 \mathrm{ng} / \mathrm{ml}$; $\mathrm{HGF}(+) \mathrm{LY} 294002(+): \mathrm{HGF}$ at $10 \mathrm{ng} / \mathrm{ml}$ with $10 \mu \mathrm{M}$ LY294002; HGF(+) CAY10452(+): HGF at $10 \mathrm{ng} / \mathrm{ml}$ with $10 \mu \mathrm{M}$ CAY10452. (B) Quantitative analysis of invaded cells. The percentage of control invasive cells was determined by setting the average invaded cell number of the control, non-treated cells as $100 \%$. Each value represents mean and SD of triplicates from 3 independent experiments. ${ }^{*}<<0.0$.

(36,37). The NF- $\kappa \mathrm{B} / \mathrm{I} \kappa \mathrm{B}-\alpha$ complex subsequently translocates $\mathrm{NF}-\kappa \mathrm{B}$ into the nucleus, where it activates apoptosis-related gene transcription (38-40). The activation of PI3K/Akt may trigger the expression of several survival genes via $N F-\kappa B$. 
A previous report has shown that $N F-\kappa B$ functional activity is required for HGF-cMet-mediated cell protection in human prostate cancer (DU-145) and Madin-Darby canine kidney (MDCK) epithelial cells (41). Similarly, our results indicate that the PI3K/Akt and $\mathrm{NF}-\kappa \mathrm{B} / \mathrm{I} \kappa \mathrm{B}$ signaling pathways in endometrial cancer RL95-2 cells may play a crucial role in the expression of COX-2 by HGF stimulation. In this study, we clarified that the stimulation by HGF enhances migration and invasion in endometrial cancer cells and showed that these effects were further attenuated by the addition of an inhibitor of I $\mathrm{B}-\alpha$ phosphorylation (BAY11-7082) and a selective COX-2 inhibitor (CAY10452).

Knockdown of COX-2 expression by shRNA or COX-2 inhibitors (celecoxib) has been shown to have potent antitumor and chemosensitization activities, comparable to the effects of taxanes in laryngeal cancer (42) and to doxorubicin in breast cancer (43). COX-2 may also become an important target for regulating the progression of uterine cancer. However, the effects of the knockdown of COX-2 on invasion, migration, and anoikis in endometrial cancer cells will need to be further examined, and it will be necessary to consider what type of material changes occur downstream of COX-2. It has been reported that $\mathrm{PGE}_{2}$ produced in the tumor microenvironment by the overexpression of COX-2 in tumoral and inflammatory cells may promote the growth of head and neck squamous carcinoma cells (44). Hence, in endometrial cancer, $\mathrm{PGE}_{2}$ produced in the tumor microenvironment by the overexpression of COX-2 may be involved in tumor progression. Further studies are needed to clarify these issues.

HGF has been shown to induce a transient expression of Snail, which is required for the induction of cell scattering and epithelial-mesenchymal transition (45). E-cadherin-mediated cell-cell adhesion is frequently lost during malignant tumor progression by gene mutation, transcriptional repression, or protein degradation (46-48). Recently, it has been shown that down-regulation of E-cadherin expression is mediated by the zinc-finger transcription factor Snail $(49,50)$. By binding to specific DNA sequences known as E-boxes in the E-cadherin promoter, Snail represses E-cadherin transcription, leading to the disruption of adherens junctions $(51,52)$. Indeed, our data showed that HGF inhibits anoikis resistance and induces migration and invasion. We also analyzed the change in apoptosis-related genes by the addition of HGF to suspended RL95-2 cells by using cDNA microarray analysis. Snail mRNA levels were approximately 2-fold up-regulated, and E-cadherin mRNA levels were reduced in RL95-2 cells stimulated with HGF (data not shown). Collectively, the results showed that HGF induced cell scattering and epithelial-mesenchymal transition, inhibited anoikis, and stimulated migration and invasion in RL95-2 cells.

In summary, HGF exhibited an anti-apoptotic action that was exerted by the PI3K/Akt pathway, triggered $\mathrm{NF}-\kappa \mathrm{B}$ activation and up-regulated COX-2 gene expression. Stimulation by $\mathrm{HGF}$ enhanced anoikis resistance and migration and invasion in endometrial cancer cells. This is the first report to clarify the intracellular signaling pathway through which HGF up-regulates COX-2 gene expression in endometrial cancer cells.

Our present study provides a novel therapeutic option for molecular-targeted treatment of endometrial cancer via the suppression of anti-apoptosis mechanisms during cancer metastasis.

\section{References}

1. Nakamura T, Nawa $\mathrm{K}$ and Ichihara A: Partial purification and characterization of hepatocyte growth factor from serum of hepatectomized rats. Biochem Biophys Res Commun 122: 1450-1459, 1984

2. Nakamura T, Nishizawa T, Hagiya M, et al: Molecular cloning and expression of human hepatocyte growth factor. Nature 342 : 440-443, 1989.

3. Funakoshi $\mathrm{H}$ and Nakamura T: Hepatocyte growth factor from diagnosis to clinical applications. Clin Chim Acta 327: 1-23, 2003.

4. Otte JM, Schmitz F, Kiehne K, Stechele HU, Banasiewicz T, Krokowicz P, Nakamura T, Folsch UR and Herzig K: Functional expression of HGF and its receptor in human colorectal cancer. Digestion 61: 237-246, 2000.

5. Natali PG, Prat M, Nicotra MR, Bigotti A, Olivero M, Comoglio PM and Di Renzo MF: Overexpression of the met/ HGF receptor in renal cell carcinomas. Int J Cancer 69: 212-217, 1996.

6. Dong G, Chen Z, Li ZY, Yeh NT, Bancroft CC and Van Waes C: Hepatocyte growth factor/scatter factor-induced activation of MEK and PI3K signal pathways contributes to expression of proangiogenic cytokines interleukin- 8 and vascular endothelial growth factor in head and neck squamous cell carcinoma. Cancer Res 61: 5911-5918, 2001.

7. Olivero M, Rizzo M, Madeddu R, Casadio C, Pennacchietti S, Nicotra MR, Prat M, Maggi G, Arena N, Natali PG, Comoglio PM and Di Renzo MF: Overexpression and activation of hepatocyte growth factor/scatter factor in human non-small cell lung carcinomas. Br J Cancer 74: 1862-1868, 1996.

8. Kiehne K, Herzig KH and Fölsch UR: c-met expression in pancreatic cancer and effects of hepatocyte growth factor on pancreatic cancer cell growth. Pancreas 15: 35-40, 1997.

9. Wagatsuma S, Konno R, Sato S and Yajima A: Tumor angiogenesis, hepatocyte growth factor, and c-Met expression in endometrial carcinoma. Cancer 82: 520-530, 1998.

10. Miyata Y, Kanetake H and Kanda S: Presence of phosphorylated hepatocyte growth factor receptor/c-Met is associated with tumor progression and survival in patients with conventional renal cell carcinoma. Clin Cancer Res 12: 4876-4881, 2006.

11. Ren Y, Cao B, Law S, et al: Hepatocyte growth factor promotes cancer cell migration and angiogenic factors expression: a prognostic marker of human esophageal squamous cell carcinomas. Clin Cancer Res 11: 6190-6197, 2005.

12. Worden B, Yang XP, Lee TL, et al: Hepatocyte growth factor/ scatter factor differentially regulates expression of proangiogenic factors through Egr-1 in head and neck squamous cell carcinoma. Cancer Res 65: 7071-7080, 2005.

13. Gao M, Fan S, Goldberg ID, Laterra J, Kitsis RN and Rosen EM: Hepatocy te growth factor/scatter factor blocks the mitochondrial pathway of apoptosis signaling in breast cancer cells. J Biol Chem 276: 47257-47265, 2001.

14. Bae-Jump V, Segreti EM, Vandermolen D and Kauma S: Hepatocyte growth factor (HGF) induces invasion of endometrial carcinoma cell lines in vitro. Gynecol Oncol 73: 265-272, 1999.

15. Yoshida S, Harada T, Iwabe T, et al: Induction of hepatocyte growth factor in stromal cells by tumor-derived basic fibroblast growth factor enhances growth and invasion of endometrial cancer. J Clin Endocrinol Metab 87: 2376-2383, 2002.

16. Park YH, Ryu HS, Choi DS, Chang KH, Park DW and Min CK: Effects of hepatocyte growth factor on the expression of matrix metalloproteinases and their tissue inhibitors during the endometrial cancer invasion in a three-dimensional coculture. Int $\mathbf{J}$ Gynecol Cancer 13: 53-60, 2003.

17. Tanaka T, Mizuno K, Umesaki N and Ogita S: Suppressed apoptotic susceptibility in human endometrial epithelial cells pretreated with hepatocyte growth factor. Clin Exp Obstet Gynecol 25: 125-128, 1998.

18. Zeng Q, Chen S, You Z, Yang F, Carey TE, Saims D and Wang CY: Hepatocyte growth factor inhibits anoikis in head and neck squamous cell carcinoma cells by activation of ERK and Akt signaling independent of NFkappa B. J Biol Chem 277: 25203-25208, 2002. 
19. Graziani A, Gramaglia D, Cantley LC and Comoglio PM: The tyrosine-phosphorylated hepatocyte growth factor/scatter factor receptor associates with phosphatidylinositol 3-kinase. J Biol Chem 266: 22087-22090, 1991

20. Bowers DC, Fan S, Walter KA, Abounader R, Williams JA, Rosen EM and Laterra J: Scatter factor/hepatocyte growth factor protects against cytotoxic death in human glioblastoma via phosphatidylinositol 3-kinase- and AKT-dependent pathways. Cancer Res 60: 4277-4283, 2000.

21. Day RM, Cioce V, Breckenridge D, Castagnino P and Bottaro DP. Differential signaling by alternative HGF isoforms through c-Met: activation of both MAP kinase and PI 3-kinase pathways is insufficient for mitogenesis. Oncogene 18: 3399-3406, 1999.

22. Smith WL: Prostanoid biosynthesis and mechanisms of action Am J Physiol 263: 181-191, 1992.

23. Nzeako UC, Guicciardi ME, Yoon JH, Bronk SF and Gores GJ: COX-2 inhibits Fas-mediated apoptosis in cholangiocarcinoma cells. Hepatology 35: 552-559, 2002.

24. Tang X, Sun YJ, Half E, Kuo MT and Sinicrope F: Cyclooxygenase-2 overexpression inhibits death receptor 5 expression and confers resistance to tumor necrosis factor-related apoptosisinducing ligand-induced apoptosis in human colon cancer cells. Cancer Res 62: 4903-4908, 2002.

25. McFall A, Ulku A, Lambert QT, Kusa A, Rogers-Graham K and Der CJ: Oncogenic Ras blocks anoikis by activation of a novel effector pathway independent of phosphatidylinositol 3-kinase. Mol Cell Biol 21: 5488-5499, 2001.

26. Frisch SM: Evidence for a function of death-receptor-related, death-domain-containing proteins in anoikis. Curr Biol 23: 1047-1049, 1999.

27. You Z, Saims D, Chen S, et al: Wnt signaling promotes oncogenic transformation by inhibiting c-Myc-induced apoptosis. J Cell Biol 157: 429-440, 2002.

28. Kanayama S, Yamada Y, Kawaguchi R, et al: Hepatocyte growth factor induces anoikis resistance by up-regulation of cyclooxygenase- 2 expression in uterine endometrial cancer cells. Oncol Rep 19: 117-122, 2008.

29. Folkman J and Moscona A: Role of cell shape in growth control. Nature 273: 345-349, 1978.

30. Wu D, Marko M, Claycombe K, Paulson KE and Maydani SN: Ceramide-induced and age-associated increase in macrophage COX-2 expression is mediated through up-regulation of NF-kappa B activity. J Biol Chem 278: 10983-10992, 2003.

31. Yeo SJ, Gravis D, Yoon JG and Yi AK: Myeloid differentiation factor 88-dependent transcriptional regulation of cyclooxygenase-2 expression by CpG DNA: role of NF-kappaB and p38. J Biol Chem 278: 22563-22573, 2003.

32. Hung JH, Su IJ, Lei HY, Wang HC, Lin WC, Chang WT, Huang W, Chang WC, Chang YS, Chen CC and Lai MD Endoplasmic reticulum stress stimulates the expression of cyclooxygenase-2 through activation of NF-kappaB and pp38 mitogen-activated protein kinase. J Biol Chem 279 46384-46392, 2004

33. Appleby SB, Ristimäki A, Neilson $K$, Narko $K$ and Hla T: Structure of the human cyclo-oxygenase-2 gene. Biochem J 302 : 723-727, 1994.

34. Barnes PJ and Karin M: Nuclear factor $\kappa \mathrm{B}$ : A pivotal transcription factor in chronic inflammatory disease. N Engl J Med 336 1066-1071, 1997.

35. Baeuerle PA and Baltimore D: NFkB: ten years after. Cell 87 $13-20,1996$
36. Sasaki K, Sato M and Umezawa Y: Fluorescent indicators for $\mathrm{Akt} /$ protein kinase B and dynamics of Akt activity visualized in living cells. J Biol Chem 278: 30945-30951, 2003.

37. Romanshkova JA and Makarov SS: NF-6B is a target of Akt in antiapoptotic PDGF signaling. Nature 401: 86-90, 1999.

38. Karin $M$ and Ben-Neriah Y: Phosphorylation meets ubiquitination: the control of $\mathrm{NF} \kappa \mathrm{B}$ activity. Annu Rev Immunol 18: 621-663, 2000

39. Perkins ND: Integrating cell-signalling pathways with NF- $\kappa \mathrm{B}$ and IKK function. Nat Rev Mol Cell Biol 8: 49-62, 2007.

40. Nakao S, Ogtata Y, Shimizu E, Yamazaki M, Furuyama S and Sugiya H: Tumor necrosis factor alpha (TNF-alpha)-induced prostaglandin $\mathrm{E} 2$ release is mediated by the activation of cyclooxygenase-2 (COX-2) transcription via NFkappaB in human gingival fibroblasts. Mol Cell Biochem 238: 11-18, 2002.

41. Fan S, Gao M, Meng Q, Laterra JJ, Symons MH, Coniglio S, Pestell RG, Goldberg ID and Rosen EM: Role of NF-kappaB signaling in hepatocyte growth factor/scatter factor-mediated cell protection. Oncogene 24: 1749-1766, 2005.

42. Wang R, Wang X, Lin F, Gao P, Dong K and Zhang HZ: shRNAtargeted cyclooxygenase (COX)-2 inhibits proliferation, reduces invasion and enhances chemosensitivity in laryngeal carcinoma cells. Mol Cell Biochem 317: 179-188, 2008.

43. van Wijngaarden $\mathrm{J}$, van Beek E, van Rossum $\mathrm{G}$, van der BC, Hoekman K, van der PG, van der Pol MA, Broxterman HJ, van Hinsbergh VW and Lowik CW: Celecoxib enhances doxorubicin-induced cytotoxicity in MDA-MB231 cells by NF-kappaB-mediated increase of intracellular doxorubicin accumulation. Eur J Cancer 43: 433-442, 2007.

44. Abrahao AC, Castilho RM, Squarize CH, Molinolo AA, dos Santos-Pinto D Jr and Gutkind JS: A role for COX2-derived PGE2 and PGE2-receptor subtypes in head and neck squamous carcinoma cell proliferation. Oral Oncol 46: 880-887, 2010

45. Grotegut S, von Schweinitz D, Christofori G and Lehembre F: Hepatocyte growth factor induces cell scattering through MAPK/Egr-1-mediated upregulation of Snail. EMBO J 25: 3534-3545, 2006.

46. Gumbiner BM: Regulation of cadherin adhesive activity. J Cell Biol 148: 399-404, 2000.

47. Thiery JP: Epithelial-mesenchymal transitions in tumour progression. Nat Rev Cancer 2: 442-454, 2002.

48. Cavallaro U and Christofori G: Cell adhesion and signalling by cadherins and Ig-CAMs in cancer. Nat Rev Cancer 4: 118-132, 2004.

49. Nieto MA: The snail superfamily of zinc-finger transcription factors. Nat Rev Mol Cell Biol 3: 155-166, 2002.

50. Huber MA, Kraut $\mathrm{N}$ and Beug $\mathrm{H}$ : Molecular requirements for epithelial-mesenchymal transition during tumor progression. Curr Opin Cell Biol 17: 548-558, 2005.

51. Barrallo-Gimeno A and Nieto MA: The Snail genes as inducers of cell movement and survival: implications in development and cancer. Development 132: 3151-3161, 2005.

52. Cano A, Perez-Moreno MA, Rodrigo I, Locascio A, Blanco MJ, del Barrio MG, Portillo F and Nieto MA: The transcription factor snail controls epithelial-mesenchymal transitions by repressing E-cadherin expression. Nat Cell Biol 2: 76-83, 2000 . 